DOI: $10.26693 / \mathrm{jmbs} 05.05 .332$

UDC 81.142:581.143:577.175.1

Kuts B. A., Kuryata V. G.

\title{
EFFECT OF TEBUCONAZOLE ON GROWTH PROCESSES, CONTENT AND REDISTRIBUTION OF CARBOHYDRATES IN HORSE BEAN SEEDLINGS UNDER SCOTOMORPHOGENESIS
}

\author{
Vinnytsia Mykhailo Kotsiubynsky State Pedagogical University, Ukraine
}

danotchka@gmail.com

The article presents a study of changes in the functioning of the source-sink system in the heterotrophic phase of development of horse beans (Vicia faba L.) under the conditions of the artificial combination of external (darkness) factor and internal factor (antigiberelline retardant) during germination. It was found that the action of the drug significantly reduced the length of the epicotyl, root and total seedling. Similarly, the dry matter mass of the seedling organs decreased. The level of using seed spare substances under the influence of retardant decreased, as evidenced by the maximum dry matter of cotyledons in plants of this variant and a decrease in the utilization of reserve substances for root and epicotyl formation during germination. Tebuconazole inhibited the breakdown of starch in the dark. The higher content of sugars in the seeds of scotomorphic plants in comparison with the control is associated with a less intensive outflow for the needs of organogenesis - the formation of root and epicotyl structures. Quantitative changes in nitrogen content in scotomorphic seeds were much smaller than changes in starch content. This indicates that the retardant in the dark inhibits the hydrolysis of the reserve protein of the seed, but the process is started after the hydrolysis of starch.

The purpose of the study was to establish the effect of tebuconazole on the processes of germination and redistribution of carbohydrates in seedlings of $\mathrm{Vi-}$ cia faba L.

Material and methods. The work was carried out on seedlings of horse beans (Vicia faba L.) of Vivat variety, which is a medium-ripe high-yielding variety with a vegetation period of 100-105 days. The variety is technological, resistant to major diseases, has high resistance to lodging, shedding of beans and their cracking.

Results and discussion. The combined effect of darkness and the drug of anti-gibberellin action of tebuconazole were used to regulate the intensity of source-sink relations during the germination of horse bean seeds. The seeds of the experimental variant were soaked for a day in $0.5 \%$ solution of the triazolederived drug tebuconazole. Tebuconazole is a transparent crystalline substance of hazard class 3 . The seeds of the control variant were soaked for 24 hours in distilled water and sown in cuvettes with wet sand.
The biological replication of the experiments is fivefold. The experiment was performed under the action of light and in dark in order to study the implementation of programs of skoto-and photomorphogenesis. Morpho-biometric parameters (root length, seedling length, dry matter weight of individual organs and the whole plant) were determined on the day of 18 of germination.

Determination of nitrogen content was carried out according to Keldal method, starch in the organs of seedlings was performed by iodometric method, to determine the content of total sugar and reducing sugar we used Bertrand method in modification by V. Kosolapov.

Conclusion. The combination of exogenous and endogenous factors during seed germination significantly changed the intensity of donor-acceptor relations in horse bean seedlings. Under the action of the drug significantly slowed the growth of seedlings in the dark. There was the decrease in the dry matter of the organs of the seedling in dark and noted lower rates of use of reserve substances for organogenesis during germination.

Keywords: retardant, scotomorphogenesis, Vicia faba L., germination.

Relation to the plans, themes, scientific research. The article is connected with the scientific programs, plans and topics that are being developed at the department. The subject of the dissertation for obtaining the scientific degree of $\mathrm{PhD}$ biological sciences from the specialty 091 "Biology" according to the extract from the protocol № 4 of the meeting of the Academic Council of the VSPU named after M. Kotsiubynskyi of October 28, 2018: "Regulation of sourcesink relations in the deposit system of assimilates growth in legume plants in period of germination".

Introduction. Among the internal factors that regulate the tension of source-sink relations, the hormonal system plays a key role. Nowadays, it has been established that light can modify the growth and morphogenesis of plants through the restructuring of the hormonal complex [1, 2].

Light is the powerful factor that significantly affects the system of assimilates' deposition -growth at the early stages of plant development, through the 
synthesis of gibberellins, controlling not only the actual process of photosynthesis (source function), but also morpho-physiological parameters of plants mediated by hierarchical sequence of sink [3].

Plants germinated in complete darkness develop according to the program of scotomorphogenesis: they lengthen the epicotyl and hypocotyl, form a hypocotyl loop, yellow cotyledons, form corrugated first leaves. The rapid elongation of these organs provides intense light output, and the tightly folded apical loop allows easy passage through soil or other substrates and protects small unfolded cotyledons and submeristematic tissues from damages. This growth strategy ensures that limited seed stocks are used sparingly, and this is a necessary condition for the survival of the photoautotroph. The main role is played by cytochrome interaction factors that allow changing the morphogenesis status [4].

Etiolated plants are characterized by active stretching of axial organs, accompanied by an increase of the content of free forms of active gibberellins, and a slowdown in the stretching of hypocotyls in light is due to a decrease in its content of free and bound forms [5].

One of the common ways to block this effect on agricultural plants is the use of retardants, in particular, such triazole-derived drugs as uninazole, paclobutrazol, pyridazine (BAS-111), azovite, amidol, and others. Tebuconazole is also widely used, as it is the standard of protection in crop production in many European countries due to its well-defined restrictive action and fungicidal effect. Tebuconazole treatment stops the active growth of the terrestrial mass, while photosynthesis continues, promoting the accumulation of plastic substances in the root, accelerates the growth of long, well-branched roots, and improves winter hardiness, water holding capacity of the plant [6].

For understanding the source-sink system functioning in conditions of photo- and scotomorphogenesis, it is important that the significant redistribution of the masses of individual organs happens [7].

There are limited data on species differences of the mechanism of regulation of the relationship between "source" and "sink" within the legume family. Thus, under the artificial influence on the systemic functioning of soybean, bean and azuki beans, changes in nitrogen supply led to the decrease of photosynthesis regulation in response to increased levels of structural carbohydrates in the leaves, causing not only decreasing of RUBISCO level, especially in beans, but also anatomical factors that led to the decrease in the physiological potential of chloroplasts [8].

The purpose of the study was to establish the effect of tebuconazole on the processes of germination and redistribution of carbohydrates in seedlings of Vicia faba L.
Material and methods. The work was carried out on seedlings of horse beans (Vicia faba L.) of Vivat variety, which is a medium-ripe high-yielding variety with a vegetation period of 100-105 days. The potential seed yield is $4.9 \mathrm{t} / \mathrm{ha}$, the grain content of protein is $34.3 \%$, vitamin C is $1.4 \mathrm{mg}$ per $100 \mathrm{~g}$, and the total sugar is $5.7 \%$. The variety is technological, resistant to major diseases, has high resistance to lodging, shedding of beans and their cracking.

The combined effect of darkness and the drug of anti-gibberellin action of tebuconazole were used to regulate the intensity of source-sink relations during the germination of horse bean seeds.

The seeds of the experimental variant were soaked for a day in a $0.5 \%$ solution of the triazolederived drug tebuconazole. Tebuconazole is a transparent crystalline substance of hazard class 3 with molecular weight of $307.8 \mathrm{Da}$ and a melting point of $104.7^{\circ} \mathrm{C}$. Solubility in organic solvents $\left(20^{\circ} \mathrm{C}\right.$, in $\left.\mathrm{g} / \mathrm{l}\right)$ constitute 0,1-1 - in hexane, 50-100 - in propanol, 50-100 - in toluene, 200-500 - in dichloromethane; in water $\left(20^{\circ} \mathrm{C}\right)-32 \mathrm{mg} / \mathrm{l}(0.032 \%)$. The drug is resistant to hydrolysis, does not irritate the skin and eyes of rabbits. $\mathrm{LD}_{50}$ for rats is $3933-5000 \mathrm{mg} /$ $\mathrm{kg}$; for birds is $1000-4488 \mathrm{mg} / \mathrm{kg}$; for earthworms $100-1000 \mathrm{mg} / \mathrm{kg}$ of dry weight. According to recommended consumption rates, the drug is not toxic to bees.

The seeds of the control variant were soaked for 24 hours in distilled water and sown in cuvettes with wet sand. The biological replication of the experiments is fivefold. The experiment was performed under the action of light and in dark in order to study the implementation of programs of skoto-and photomorphogenesis. Morpho-biometric parameters (root length, seedling length, dry matter weight of individual organs and the whole plant) were determined on the day of 18 of germination.

Determination of nitrogen content was carried out according to Keldal method, starch in the organs of seedlings was performed by iodometric method, to determine the content of total sugar and reducing sugar we used Bertrand method in modification by $\mathrm{V}$. Kosolapov [9]. The analytical repeatability of studies is fivefold. Statistical processing of the results was performed using the computer program "Statistica-6". The reliability of the difference between control and experiment was determined by Student's t-test. The tables and figures show the arithmetic mean values and their standard errors.

Results and Discussion. The obtained data indicate a significant decrease in the growth rate of horse bean seedlings during treatment with tebuconazole, as well as the decrease of utilization intensity of cotyledon reserve substances under scotomorphogenesis conditions (Figure 1). 
There was a significant decrease of the use rate of seed reserves for the needs of organogenesis of epicotyls during scotomorphogenesis on the day of 18 of germination under the influence of the triazole-derived drug (Figure 2).

The decrease of the utilization rate intensity of reserve substances from cotyledons is also confirmed by significantly lower rates of dry matter of epicotyl (by $28.2 \%$ ) and root (by $9.52 \%$ ) of plants in the variant of tebuconazole compared with control under scotomorphogenesis.

There presents only limited data on the effect of gibberellins on the use of non-starch reserve substances, in particular proteins and lipids [10]. The study showed that under the action of gibberellin in comparison with the control there was an increase of the aboveground part's and root system growth rate of seedlings that contain different types of reserve substances - starch (corn), protein (beans) and oil (zucchini). Gibberellin plays a universal role in germination processes, regardless of the type of seed reserve, and its effect is enhanced in dark. Under the action of retardants that block the formation of gibberellins, the germination process was slowed down in dark $[11,10]$.

Horse beans are characterized by the fact that the main reserves of seeds are represented by both starch and protein. Given the decrease in the values of the utilization rate of seed reserves for growth and formation of vegetative organs of the seedling under the influence of tebuconazole, an analysis of the carbohydrate content in bean seedlings was performed (Table 1).

Our data indicated that under conditions of scotomorphogenesis, the content of carbohydrates in the roots and epicotyls of the control variant of the experiment was significantly higher than in seedlings under tebuconazole effect. The treatment of tebuconazole significantly reduced the content of reducing sugars in the seeds.

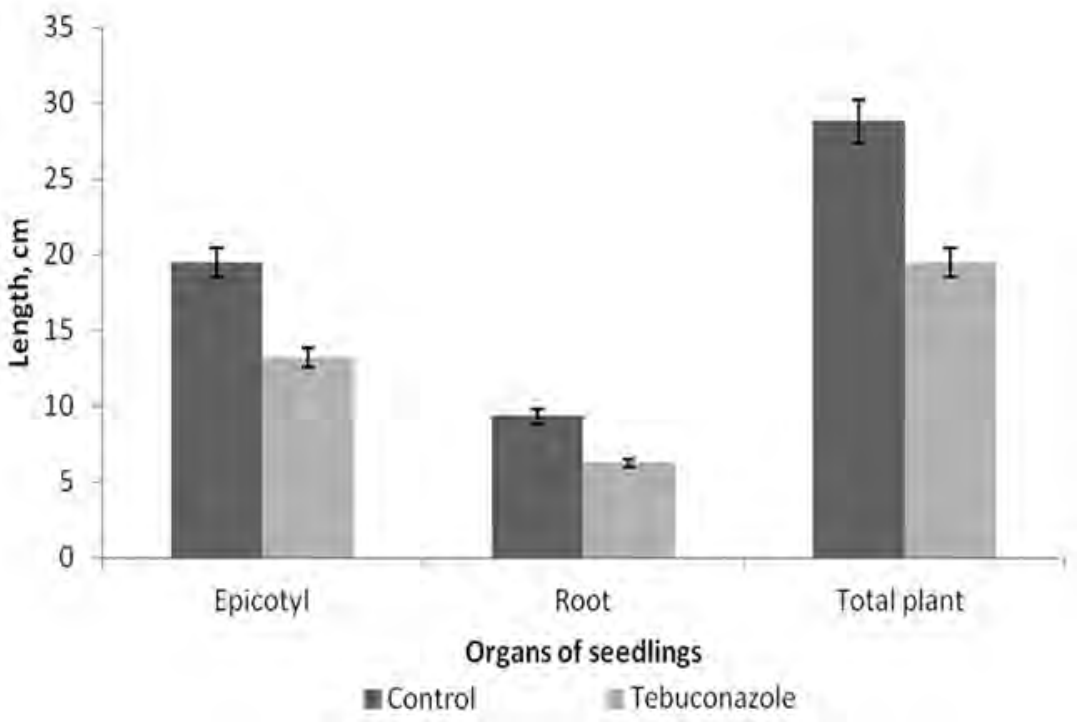

Figure 1. The effect of tebuconazole on the growth processes of horse beans under conditions of scotomorphogenesis

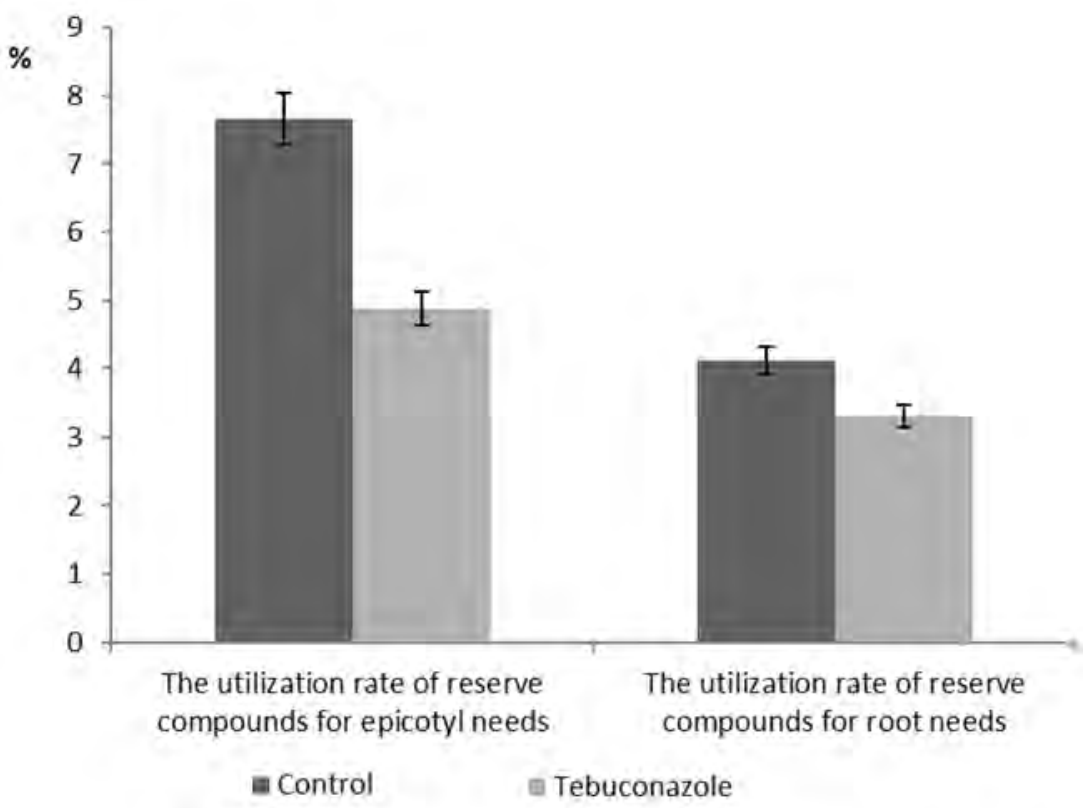

Figure 2. The effect of tebuconazole on the intensity of utilization of reserve substances of horse bean seeds under conditions of scotomorphogenesis

Table 1 - The effect of tebuconazole on the sugar content in the organs of horse bean seedlings under conditions of scotomorphogenesis (the day of 18 of germination, \% by weight of dry matter)

\begin{tabular}{|c|c|c|c|c|}
\hline Plant organs & $\begin{array}{c}\text { Variant of the } \\
\text { experiment }\end{array}$ & $\begin{array}{c}\text { Total sugar, } \\
\%\end{array}$ & $\begin{array}{c}\text { Reducing } \\
\text { sugars, } \%\end{array}$ & Sucrose, \% \\
\hline \multirow{2}{*}{ Root } & Control & $1.27 \pm 0.06$ & $0,94 \pm 0,047$ & $0.33 \pm 0.17$ \\
\cline { 2 - 5 } & Tebuconazole & $1,08 \pm 0,054^{*}$ & $0,8 \pm 0,04^{*}$ & $0,28 \pm 0,014$ \\
\hline \multirow{2}{*}{ Epicotyl } & Control & $1.78 \pm 0.09$ & $0,98 \pm 0,049$ & $0.80 \pm 0.04$ \\
\cline { 2 - 5 } & Tebuconazole & $1,11 \pm 0,055^{*}$ & $0,82 \pm 0,04^{*}$ & $0,29 \pm 0,014^{*}$ \\
\hline \multirow{2}{*}{ Cotyledons } & Control & $7.76 \pm 0.33$ & $4,64 \pm 0,232$ & $3.14 \pm 0.15$ \\
\cline { 2 - 5 } & Tebuconazole & $9,69 \pm 0,484^{*}$ & $5,44 \pm 0,272^{*}$ & $4,25 \pm 0,21$ \\
\hline
\end{tabular}

Note: * - the difference is significant at $P \leq 0.05$ 
However, there was an intensification of the redistribution of carbohydrates from seed. The decrease in sucrose content in epicotyl and seedling root, which was observed in scotomorphic plants under the influence of tebuconazole, in our opinion, is due to inhibition of starch hydrolysis, which is the result of retardant exposure and blocking gibberellins [12]. This is evidenced by the obtained indicators of starch content in seeds in the variant of tebuconazole, which are slightly lower than in control and significantly lower than the mass of dry seeds (Figure 3).

The decrease in the content of total nitrogen (by 13.53\%) and its fractions (protein - by $18.46 \%$ and non-protein - by $5.59 \%$ ) in sprouted cotyledons, as well as an increase

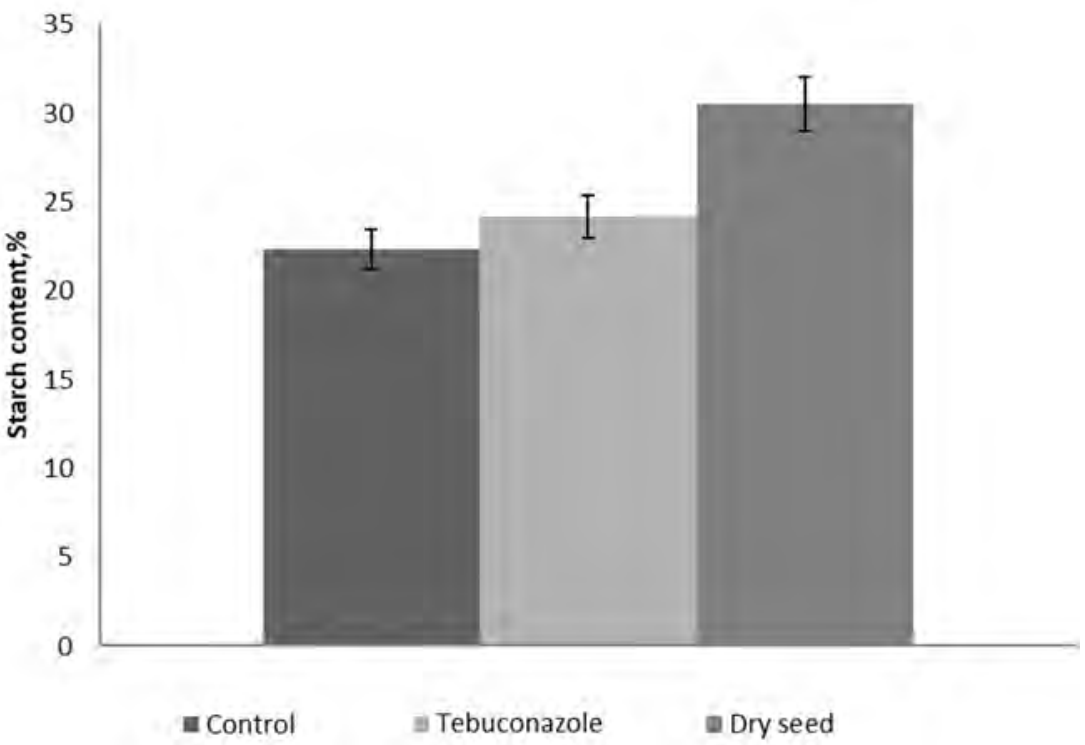

Figure 3. The effect of tebuconazole on the intensity of hydrolysis of starch of horse bean seeds under conditions of scotomorphogenesis

( $\%$ by weight of dry matter, the day of 18 of germination) in its content in epicotyl (by $24.93 \%, 21.87 \%$ and $16.21 \%$, respectively) and in the root of scotomorphic seedlings (by $24.93 \%, 41.37 \%$ and $3.34 \%$, respectively) under the action of tebuconazole. Changes in the nitrogen content in the seeds of scotomorphic plants on the $18^{\text {th }}$ day of germination were much smaller than the changes in the starch content. Therefore, the process of protein re-utilization begins after intensive hydrolysis of starch. In our opinion, this is due to the biodilution of the element by the organic matter of these organs due to the more intensive growth rates of scotomorphic plants.

The same trend is found in the germination of corn seeds: primarily the use of starch takes place, and protein compounds are used at later stages of germination [10].

Conclusion. The combination of exogenous and endogenous factors during seed germination significantly changed the intensity of donor-acceptor relations in horse bean seedlings. Under the action of the drug significantly slowed the growth of seedlings in

the dark. There was the decrease in the dry matter of the organs of the seedling in dark and noted lower rates of use of reserve substances for organogenesis during germination.

Tebuconazole inhibited starch hydrolysis under conditions of scotomorphogenesis. The low content of total sugar in the seeds of scotomorphic plants under the action of the retardant is explained by less intensive outflow for the needs of organogenesis - the formation of root and epicotyl structures. Quantitative changes in the nitrogen content in the cotyledons of scotomorphic plants during germination were much smaller than changes in the starch content. This suggests that in the dark, tebuconazole inhibits the hydrolysis of seed reserve protein, but less intensely compared to the rate of starch hydrolysis.

Prospects for further research will be the determination of anatomic peculiarities of seedlings to identify the differences between skotomorphic and photomorphic plants of horse beans.

\section{References}

1. Kutschera U, Briggs WR. Seedling development in buckwheat and the discovery of the photomorphogenic shade-avoidance response. Plant Biol (Stuttg). 2003; 15(6): 931-940.

2. De Wit M, Pierik R. Photomorphogenesis and Photoreceptors. Canopy Photosynthesis: From Basics to Applications. 2016; 42: 171-186.

3. Poprotska IV. Diia svitla ta ristrehuliuiuchykh rechovyn na napruzhenist donorno-aktseptornykh vidnosyn $v$ roslyni u protsesi prorostannia. Akt probl suchasn biol ta metodky yii vyklad. Zbirn nauk prats zvit nauk konf vyklad za 2016-2017 VDPU im M Kotsiubynskoho; vidpov red VH Kur'iata. Vinnytsia; 2017. 2017: 103-120. [Ukrainian]

4. Alabadi D, Gil J, Blázquez M, García-Martínez José. Gibberellins Repress Photomorphogenesis in Darkness. Plant physiology. 2004; 134: 1050-7. doi: 10.1104/pp.103.035451

5. Josse, EM, Halliday KJ. Skotomorphogenesis: The Dark Side of Light Signalling. Current Biology. 2008; 18(24): 1144-1146. 
6. Vlasenko NG, Teplyakova OI, Meteleva ES. Effektivnyiy preparat dlya predposevnoy obrabotki semyan zernovyih kulbtur na osnove kompleksov tebukonazola s polisaharidami laminarii. Uspehi sovremennogo estestvoznaniya. 2017; 12: 28-37. [Ukrainian]

7. Poprotska IV. Rehuliatsiia donorno -aktseptornykh vidnosyn u roslyn v systemi «depo asymiliativ - rist» $u$ protsesi prorostannia. Vinnytsia: TOV «Nilan-LTD»; 2017. 122 p. [Ukrainian]

8. Sugiura D, Betsuyaku E, Terashima I. Interspecific differences in how sink-source imbalance causes photosynthetic downregulation among three legume species. Annals of botany. 2019; 123: 715-726. doi: 10.1093/aob/mcy204

9. AOAC. Official methods of analysis of association of analytical chemist international 18th ed. Rev. 3.2010. Asso of Analytical Chemist. Gaithersburg-Maryland, USA; 2010.

10. Poprotska I, Kuryata V, Khodanitska O. Effect of gibberellin and retardants on the germination of seeds with different types of reserve substances under the conditions of skoto- and photomorphogenesis. Biologija. 2019; 65(4): 296-307.

11. Kuryata VG, Poprotska IV, Rogach TI. The impact of growth stimulators and retardants on the utilization of reserve lipids by sunflower seedlings. Regul Mech Biosyst. 2017; 8(3): 317-322.

12. Kuts $B$, Kuryata V. Effect of gibberellin on the intencivity of usage of reserve substances deposited in Vicia faba I. seeds at the heterotrophic development phase. Magyar Tudományos Journal. Budapest, Hungary. $2020 ; 41$ (1): 3-8.

Удк 81.142:581.143:577.175.1

\section{ДІЯ ТЕБУКОНАЗОЛУ НА РОСТОВІ ПРОЦЕСИ, ВМІСТ ТА ПЕРЕРОЗПОДІЛ ВУГЛЕВОДІВ У ПРОРОСТКАХ КІНСЬКИХ БОБІВ ЗА УМОВ СКОТОМОРФОГЕНЕЗУ \\ Куц Б. О., Кур'ята В. Г.}

Резюме. В статті представлено дослідження змін у функціонуванні донорно - акцепторної системи у гетеротрофну фазу розвитку кінських бобів (Vicia faba L.) за умов штучного комбінування зовнішнього (темрява) чинника та внутрішнього фактору (ретарданту антигіберелінової дії) в період проростання. Встановлено, що за дії препарату достовірно знижувалася довжина епікотилю, кореня та проростка в цілому. Аналогічно цьому зменшувалася маса сухої речовини органів проростку. Знижувався рівень використання запасних речовин насінини під впливом ретарданту, про що свідчить максимальна маса сухої речовини сім'ядолей у рослин цього варіанту та зниження коефіцієнту використання резервних речовин на потреби формування кореня та епікотилю в процесі проростання. Тебуконазол інгібував розщеплення крохмалю в темряві. Більш високий вміст суми цукрів у насінині скотоморфних рослин порівняно з контролем пов'язаний з менш інтенсивним відтоком на потреби органогенезу - формування структур кореня та епікотиля. Кількісні зміни у вмісті азоту в насінні скотоморфних рослин були значно меншими, ніж зміни у вмісті крохмалю. Це свідчить про те, що ретардант в темряві гальмує гідроліз резервного білка насінини, однак процес запускається після гідролізу крохмалю.

Метою дослідження є встановлення впливу тебуконазолу на процеси проростання та перерозподіл вуглеводів у проростках Vicia faba $L$.

Роботу проведено на проростках кінських бобів (Vicia faba L.) сорту «Віват», що є середньостиглим високопродуктивним сортом з періодом вегетації 100-105 діб. Сорт технологічний, стійкий до основних хвороб, має високі показники стійкості до вилягання, осипання бобів та їх розтріскування.

У роботі застосовано комбінований вплив темряви та препарату антигіберелінової дії тебуконазолу для регуляції напруженості донорно-акцепторних відносин в період проростання насіння бобів кінських. Насіння експериментального варіанту на добу замочували в 0,5\% розчині триазолпохідного препарату тебуконазолу. Тебуконазол - прозора кристалічна речовина 3 класу небезпеки.

Насіння контрольного варіанту замочували на 24 години у дистильованій воді та висівали у кювети з вологим піском. Біологічна повторність дослідів п'ятикратна. Дослід проводили за темряви з метою дослідження реалізації програм скотоморфогенезу. Морфо-біометричні показники (довжина кореня, довжина проростку, маса сухої речовини окремих органів та цілої рослини) визначали на 18 -й день проростання.

Визначення вмісту азоту здійснювали за методикою Кельдаля, крохмалю в органах проростків проводили йодометричним методом, для встановлення вмісту суми цукрів, редукуючих цукрів застосовували методику за Бертраном модифікації В. Косолапова.

Ключові слова: ретардант, скотоморфогенез, Vicia faba L., проростання. 
Удк 81.142:581.143:577.175.1

ДЕЙСТВИЕ ТЕБУКОНАЗОЛА НА РОСТОВЫЕ ПРОЦЕССЫ, СОДЕРЖАНИЕ И ПЕРЕРАСПРЕДИЛЕНИЕ УГЛЕРОДОВ

В ПРОРОСТКАХ КОНСКИХ БОБОВ В УСЛОВИЯХ СКОТОМОРФОГЕНЕЗА

Куц Б. А., Курьята В. Г.

Резюме. В статье представлено исследование изменений в функционировании донорноакцепторной системы в гетеротрофную фазу развития конских бобов (Vicia faba L.) в условиях искусственного комбинирования внешнего (темнота) фрактора и внутреннего фрактора (ретарданты антигиббереллинового действия) в период прорастания. Определено, что при действии препарата достоверно снижалась длина эпикотиля, корня и проростка в целом. Аналогично этому уменьшалась масса сухого вещества органов проростка. Снижался уровень использования запасных веществ семян под влиянием ретардантов, о чем свидетельствует максимальная масса сухого вещества семядолей у растений этого варианта и снижение коэффициента использования резервных веществ на необходимости формирования корня и эпикотиля в процессе прорастания. Тебуконазол ингибировал расщепления крахмала в темноте. Более высокое содержание суммы сахаров в семенах скотоморфных растений по сравнению с контролем связано с менее интенсивным оттоком на нужды органогенеза формирование структур корня и эпикотиля. Количественные изменения в содержании азота в семенах скотоморфных растений были значительно меньше, чем изменения в содержании крахмала. Это свидетельствует о том, что ретардант в темноте тормозит гидролиз резервного белка семян, однако процесс запускается после гидролиза крахмала.

Целью исследования является определение влияния тебуконазола на процессы прорастания и перераспределение углеводов в проростках Vicia faba $L$.

Работа проведена на проростках конских бобов (Vicia faba L.) сорта «Виват», что является среднеспелым высокопроизводительным сортом с периодом вегетации 100-105 суток. Сорт технологический, устойчив к основным болезням, имеет высокие показатели устойчивости к полеганию, осыпанию бобов и их растрескиванию.

В работе применены комбинированное воздействие темноты и препарата антигиббереллинового действия тебуконазола для регуляции напряженности донорно-акцепторных отношений в период прорастания семян бобов. Семена экспериментального варианта на сутки замачивали в 0,5\% растворе триазолпроисходного препарата тебуконазола. Тебуконазол - прозрачное кристаллическое вещество 3 класса опасности.

Семена контрольного варианта замачивали на 24 часа в дистиллированной воде и высевали в кюветы с влажным песком. Биологическая повторность опытов пятикратная. Опыт проводили в темноте с целью исследования реализации программ скотоморфогенеза. Морфо-биометрические показатели (длина корня, длина проростков, масса сухого вещества отдельных органов и целого растения) определяли на 18-й день прорастания.

Определение содержания азота осуществляли по методике Кельдаля, крахмала в органах проростков проводили йодометрическим методом, для определения содержания суммы сахаров, редуцирующих сахаров применяли методику по Бертрану в модификации В. Косолапова.

Ключевые слова: ретардант, скотоморфогенез, Vicia faba L., прорастание.

The authors of this study confirm that the research and publication of the results were not associated with any conflicts regarding commercial or financial relations, relations with organizations and/or individuals who may have been related to the study, and interrelations of coauthors of the article. 